high aggressive content related to the parental-drive. Simmons conducted a large number of experiments with -waders to elicit predator-reactions. Among other interesting things he found that most species showed far less fear toward a human lying down than to one standing. He points to a need for objective methods of in- vestigation and interpretation in the study of predator-reactions and indicates a need for precise work on individual species.

I should like to thank Dr. Frank McKinney, Delta Waterfowl Research Station, for critical examination of this note and for calling my attention to the work by Simmons.

\title{
Great Horned Owl Distraction Display
}

by R. W. Fyfe, Saskatchewan Museum of Natural History.

Predatory birds rarely exhibit any form of distraction display or "injury feigning" when their nests are approached. Bent (Life Histories of North American Birds of Prey, Vol. II) indicated that such display is exhibited only occasionally by predatory - species - other than the Long-eared Owl (Asio otus) in which it occurs regularly. On two separate occasions, May 14 and June 3, 1959, I witnessed distraction display by a Great Horned Owl (Bubo virginianus) when we visited the nest. On May 14 when we approached the nest, which then contained two newly-hatched young, both parents flew to the opposite hillside about 100 yards distant and remained standing on the ground continually hooting and screaming as we approached the nest. Then one bird suddenly began walking slowly, alternately dragging and flopping its right wing on the ground. At the same time, presumably the same bird began to utter most un-owl-like screams. This display continued for a short period while the bird moved about twenty feet over the ground; the bird then stood still though occasionally screaming as before. On our second visit, the birds behaved as before except that when flying to the hillside, one bird suddenly fell into low brush as if it had been shot. A moment later it reappeared, walking and dragging its wing as before, all the while uttering the same cry of distress. In each case, the display had lasted only while we were in the immediate vicinity of the nest.

\section{Great Horned Owl Banding}

by Stuart Houston, Yorkton.

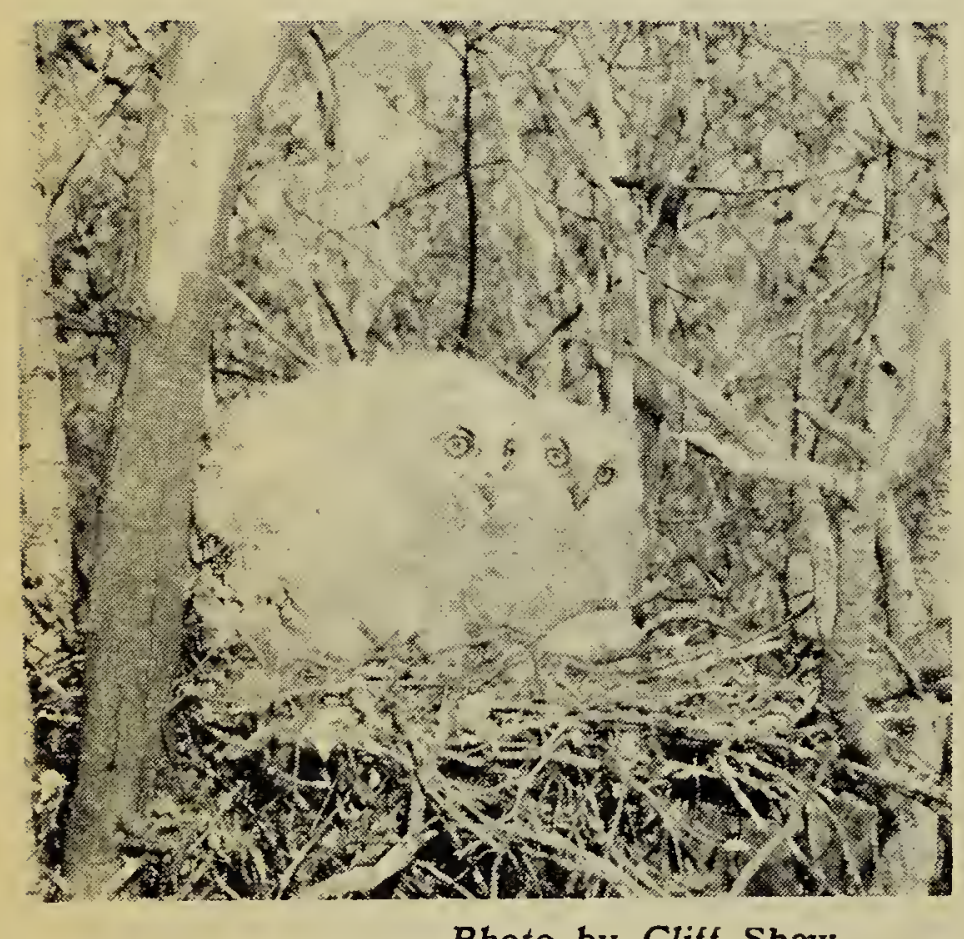

Photo by Cliff Shaw

Young Great Horned Owls in nest

Our 1958 owl banding (22 young in 10 nests) was considered worthy of mention as "a fine example of field work" in the continent-wide summary of nesting records in the October 1958 issue of Audubon Field Notes. But my enthusiastic helper, Bill Horseman, was still not satisfied and determined that we should set a new record in 1959.

Sunday, May 17, was planned as the "big day" and we started out at 5 a.m. for the Saltcoats district. Horseman knew of ten nests and an additional eight had been located by patients of mine. We were encouraged to find that only one nest had been deserted and none destroyed, of the eighteen nests we visited that day. The residents of this area seem more tolerant of owls than they were in the past.

The number of young raised to maturity is often a fairly good index of the food supply; judging by this the owls had a good year. One nest contained four young ready to leave the nest, eight nests had three young 


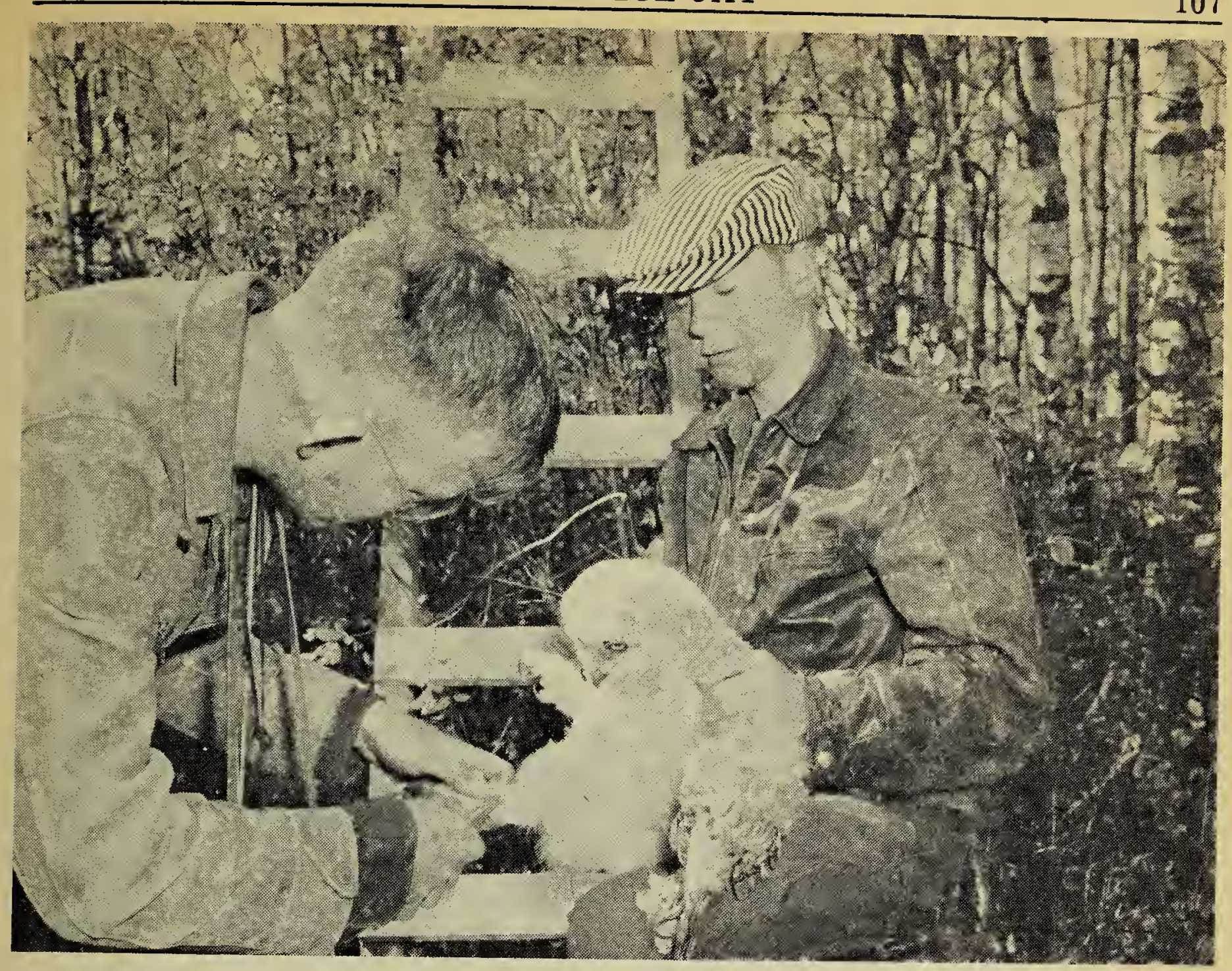

Photo by Cliff Shaw

Dr. Houston (left) and Bill Horseman (right) band a young Great Horned Owl.

each, four nests had two, and four had one. Thus we banded 40 Great Horned Owls in a single day. I was fortunate in having three excellent climbers: Bill Horseman and his friend Lorne Barker of 'S ltcoats, and Gary Anweiler of Melville.

Horseman continued to scout for nests, and in addition one was found by Anweiler at Melville and four at Stornoway by Ken Swartz and Stanley Zazelenchuk. These necessitated a few early morning and late evening trips until finally the last two late nests were visited on June 6. The final total was 70 Great Horned Owls banded; 67 for 30 nests, plus three other young already out of the nest and flying short distances.

We saw a good sampling of the nestling's food in each nest. Rabbits and pocket gophers were the predominant items, but grebes, ducks, crows and rats were frequently found. Not a single upland game bird was represented, though a Ruffed Grouse was drumming on his wellworn $\log$ less than twenty feet from the base of the tree containing one of the owl's nests. Neither was a single domestic fowl encountered in any of the thirty nests examined.

We have also banded 12 Longeared Owls in four nests and 16 Red-tailed Hawks in nine nests to date this year.

\section{A Study of Early Spring Nesting of the Horned Lark in the Area of Kindersley, Sask.}

\section{by Glen A. Fox, Kindersley, Sask.}

During April of 1959, I made a study of eight nests of the Horned Lark (Eremophila alpestris). The study was carried out over a period of 35 days and a total of 70 hours. Observations of incubation and brooding were aided by a $20 \mathrm{x}$ spotting scope. None of the birds studied was marked.

\section{ENVIRONMENT}

The study area was a typical grassland area of the prairies. The nests were located on a golf course. Vegetation in this area included prairie grasses, sage, cactus, dock and cattails. Mammals noted in this area were the meadow vole, deer mouse, masked shrew, Richardson's ground 